\title{
HUBUNGAN KADAR HEMATOKRIT DENGAN KELAS NYHA PADA PASIEN GAGAL JANTUNG KONGESTIF OBESITAS SENTRAL YANG DIRAWAT JALAN DAN DIRAWAT INAP DI RSUP PROF. DR. R. D. KANDOU
}

\author{
${ }^{1}$ Ekky Malisan \\ ${ }^{2}$ Frans E. Wantania \\ ${ }^{2}$ Linda W. A. Rotty \\ ${ }^{1}$ Kandidat Skripsi Fakultas Kedokteran Universitas Sam Ratulangi Manado \\ ${ }^{2}$ Bagian Ilmu Penyakit Dalam Fakultas Kedokteran Universitas Sam Ratulangi Manado \\ Email: emalisan11_178@yahoo.com
}

\begin{abstract}
Obesity and hematocrit play a role in the inflammatory process, infection, systemic heart disease, and thrombosis process, therefore, they can lead the exacerbation of congestive heart failure to become acute heart failure. This study aimed to determine the correlation between the hematocrit level and NYHA class of congestive heart failure and central obesity patients (in-patients and out-patients). This was an observational analytical study with a cross sectional design. Samples were CHF patients with central obesity at Prof. Dr. R. D. Kandou Hospital Manado from November 2014 until January 2015. Samples consisted of 20 inpatients and 20 out-patients selected by a purposive sampling method. The coefficient correlation Spearman test showed a correlation $\mathrm{r}=0.558$ with a $\mathrm{P}$-value $=0.000(\mathrm{P}<0.05)$. Conclusion: There was a significant correlation of hematocrit level and the NYHA class of CHF patients (in-patients and out-patients) with central obesity.

Keywords: congestive heart failure, central obesity, hematocrit, NYHA class
\end{abstract}

\begin{abstract}
Abstrak: Obesitas dan hematokrit dapat berperan dalam proses inflamasi, infeksi, penyakit jantung sistemik, dan proses trombosis sehingga dapat menyebabkan eksaserbasi gagal jantung kongestif menjadi gagal jantung akut. Penelitian ini bertujuan untuk mengetahui hubungan kadar hematokrit dengan kelas NYHA pada pasien gagal jantung kongestif obesitas sentral yang dirawat jalan dan dirawat inap. Penelitian ini bersifat analitik observasional dengan metode potong lintang. Sampel penelitian ialah pasien gagal jantung kongestif obesitas sentral di RSUP Prof. Dr. R. D. Kandou Manado yang berlangsung dari bulan November 2014-Januari 2015. Sampel terdiri dari 20 pasien rawat jalan dan 20 pasien rawat inap yang dipilih secara purposive sampling. Hasil analisis korelasi spearman menunjukkan korelasi $\mathrm{r}=0,558$ dengan nilai $\mathrm{p}=0,000(\mathrm{p}<0,05)$. Simpulan: Terdapat tingkat hubungan yang sedang dan bermakna antara kadar hematokrit dan kelas NYHA pada pasien gagal jantung kongestif obesitas sentral yang dirawat jalan dan dirawat inap.
\end{abstract}

Kata kunci: gagal jantung kongestif, obesitas sentral, hematokrit, kelas NYHA

Gagal jantung kongestif atau congestive heart failure (CHF) adalah keadaan patofisiologis dimana jantung tidak stabil menghasilkan curah jantung yang adekuat sehingga perfusi jaringan tidak adekuat, dan/atau peningkatan tekanan pengisian diastolik pada ventrikel kiri sehingga tekanan kapiler paru meningkat. ${ }^{1}$ New York Heart Assosiation (NYHA) membuat klasifikasi fungsional CHF dalam 4 kelas yaitu kelas I-IV. ${ }^{2}$

Prevalensi gagal jantung di negara 
berkembang cukup tinggi dan makin meningkat, sehingga merupakan masalah kesehatan yang utama. Setengah dari pasien yang terdiagnosis gagal jantung masih punya harapan hidup 5 tahun. Penelitian Framingham menunjukkan mortalitas 5 tahun sebesar $62 \%$ pada pria dan $42 \%$ wanita. ${ }^{3}$ Menurut American Heart Assosiation, 5,3 juta Amerika memiliki gagal jantung kongestif, 660.000 kasus baru yang didiagnosis setiap tahun, dengan kejadian mendekati 10 per 1000 penduduk dari antara orang tua dari 65 tahun. Diperkirakan angka kematian yang berhubungan dengan gagal jantung adalah sekitar 287.000 orang. Prevalensi gagal jantung mengikuti pola eksponensial, yang meningkat dengan usia dan mempengaruhi 6-10\% dari orang di atas usia 65 tahun. $^{4-6}$ Tampaknya bahwa keberhasilan dalam merawat kondisi jantung lainnya seperti infark miokard, penyakit jantung katup, dan aritmia telah meningkatkan prevalensi gagal jantung sekarang bahwa pasien bertahan hidup lebih lama. Gagal jantung kongestif merupakan penyebab utama penerimaan ke rumah sakit di kalangan orang tua. ${ }^{5}$

Di Indonesia sendiri belum ada angka pasti tentang prevalensi penyakit gagal jantung. Namun, data dari Riset Kesehatan Dasar Nasional menyebutkan bahwa penyakit jantung merupakan penyebab kematian yang mendominasi pada kelompok umur 55-65 tahun di Indonesia. ${ }^{7}$ Di RS Jantung Harapan Kita, setiap hari terdapat sekitar 400-500 pasien berobat jalan dan sekitar $65 \%$ ialah pasien gagal jantung. ${ }^{8}$

Pada keadaan selanjutnya pasien gagal jantung kongestif juga dapat menjadi kondisi akut atau eksaserbasi akut dan berkembang secara tiba-tiba menjadi gagal jantung akut (GJA) pada infark miokard. ${ }^{9}$ GJA dapat berupa serangan pertama gagal jantung atau perburukan dari gagal jantung kronik sebelumnya. Banyak kondisi kardiovaskular dan juga faktor-faktor yang dapat mencetuskan terjadinya gagal jantung akut seperti penyakit jantung iskemik: sindrom koroner akut (SKA), hipertensi, dekompensasi pada gagal jantung kronik: tidak patuh minum obat, infeksi, dan lainlain. SKA merupakan kausa yang paling sering pada gagal jantung akut yang baru. Rata-rata perawatan di rumah sakit akibat GJA dari The Euro Heart Survey 9 hari. Dari studi registry pasien yang dirawat dengan GJA hampir separuh di antaranya dirawat kembali paling tidak sekali dalam 12 bulan pertama. ${ }^{10}$

Obesitas atau kegemukan menurut World Health Organization (WHO) didefinisikan sebagai akumulasi lemak abnormal atau berlebihan yang dapat mengganggu kesehatan. Obesitas merupakan penyebab terjadinya penyakit jantung dan pembuluh darah (kardiovaskuler). Populasi dunia sebesar $65 \%$ tinggal di negara yang kelebihan berat badan dan dibandingkan pria yang lebih dari 200 juta ternyata hampir 300 juta wanita mengalami obesitas. Sekitar 2,8 juta orang dewasa meninggal setiap tahun akibat obesitas. $^{11}$

Berdasarkan laporan RISKESDAS tahun 2010 prevalensi tertinggi untuk obesitas di Indonesia adalah di Provinsi Sulawesi Utara (37,1\%), dan yang terendah adalah $13,0 \%$ di provinsi Nusa Tenggara Timur. Prevalensi obesitas cenderung mulai meningkat setelah usia 35 tahun ke atas dan menurun kembali setelah usia 60 tahun ke atas, baik pada laki-laki maupun perempuan. ${ }^{12}$ Obesitas memiliki hubungan yang erat dengan tingginya kejadian penyakit kardiovaskular. Obesitas dapat meningkatkan kadar trigliserid yang buruk untuk kesehatan jantung dan menurunkan kadar high density lipoprotein (HDL) yang bersifat kardioprotektif. Selain itu, seiring meningkatnya obesitas, meningkat juga angka hipertensi. Obesitas juga dapat menyebabkan disfungsi diastolik dan berhubungan dengan memburuknya fungsi sistolik. ${ }^{13}$ Obesitas juga berkaitan dengan terjadinya proses infamasi dan aterosklerosis yang bisa menyebabkan terjadinya trombosis dan penyebab terjadinya sindrom koroner akut yang pada akhirnya nanti dapat meyebabkan eksaserbasi akut menjadi gagal jantung akut. ${ }^{14}$ 
Hematokrit merupakan persentasi sel dari darah dan sering dijadikan sebagai parameter untuk menilai penurunan massa eritosit, selain kadar hemoglobin dan hitung eritrosit. ${ }^{15}$ Nilai normal untuk pria berkisar $42-53 \%$, sedangkan untuk wanita 38-46\%. ${ }^{16}$ Peningkatan jumlah hematokrit dalam sirkulasi darah dapat meningkatkan viskositas darah yang kemudian akan menyebabkan penurunan kecepatan aliran darah sehingga dapat menyebabkan trombosis dan penurunan laju transport oksigen ke jaringan dan dapat menyebabkan iskemik/infark seperti di otak, mata, telinga, jantung, dan ekstremitas. ${ }^{17}$

Obesitas dan hematokrit dapat berperan dalam proses inflamasi, infeksi, penyakit jantung sistemik seperti SKA, dan proses trombosis sehingga dapat menyebabkan terjadinya eksaserbasi gagal jantung kongestif (NYHA kelas 1 dan 2) menjadi gagal jantung akut (NYHA kelas 3 dan 4). Berdasarkan latar belakang tersebut, penulis terdorong untuk melakukan penelitian mengenai hubungan kadar hematokrit dengan kelas NYHA pada pasien gagal jantung kongestif obesitas sentral yang dirawat jalan dan dirawat inap.

\section{METODE PENELTIAN}

Penelitian ini menggunakan metode penelitian analitik observasional dengan pendekatan potong lintang. Penelitian ini memiliki 2 hipotesis :

$\mathrm{H}_{0}$ : Tidak ada hubungan kadar hematokrit dengan kelas NYHA pada pasien gagal jantung kongestif obesitas sentral.

$\mathrm{H}_{1}$ : Ada hubungan kadar hematokrit dengan kelas NYHA pada pasien gagal jantung kongestif obesitas sentral.

Penelitian ini dilakukan di Instalasi Pusat Jantung Pembuluh Darah dan Otak Terpadu dan Irina F Jantung RSUP Prof. Dr. R. D. Kandou Manado pada November 2014Januari 2015.

Populasi penelitian ialah pasien yang didiagnosis gagal jantung kongestif yang berobat ke Poliklinik Kardiologi dan yang dirawat inap di RSUP Prof. Dr. R. D. Kandou Manado. Sampel penelitian ialah pasien gagal jantung kongestif obesitas sentral yang dirawat jalan dan dirawat inap di RSUP Prof. Dr. R. D. Kandou Manado. Teknik pengambilan sampel menggunakan purposive sampling atau judgmental sampling yang dilakukan dengan memilih subjek berdasarkan kriteria spesifik yang ditetapkan peneliti.

Penelitian ini merupakan penelitian awal sehingga besar sampel yang diambil sebesar 20 orang pasien gagal jantung kongestif obesitas sentral yang dirawat jalan dan 20 orang pasien gagal jantung kongestif obesitas sentral yang dirawat inap. Kriteria inklusi sampel penelitian yaitu: 1) pasien yang bersedia untuk jadi responden/sampel; 2) diagnosis pasti gagal jantung kongestif kelas fungsional I, II,III, IV; 3) laki-laki obesitas sentral dengan LP $\geq 90 \mathrm{~cm}$ dan perempuan obesitas sentral dengan $L P \geq 80 \mathrm{~cm}$; 4) pasien dengan umur 30-80 tahun. Kriteria ekslusi yaitu: 1) pasien yang menolak untuk jadi responden/sampel; 2) adanya penyakit penyerta seperti DHF, PPOK, dan polisitemia; 3) anemia dengan $\mathrm{Hb}<10$ gr/dl.

Jenis data yang digunakan ialah data primer. Pengolahan data dilakukan dengan menggunakan program komputer SPSS versi 20 dengan mengentri satu per satu data sampel, kelompok variabel bebas, dan terikat, kemudian data disajikan dengan cara menyusunnya dalam bentuk tabel, diagram, dan persentase. Analisis data yang digunakan yaitu uji Korelasi dan uji $\mathrm{T}$ independen.

\section{HASIL PENELITIAN Analisis Univariat}

Tabel 1 memperlihatkan distribusi pasien gagal jantung kongestif berdasarkan kelas NYHA. Jumlah terbanyak ialah NYHA kelas II sebesar 42,5\%.

Tabel 2 memperlihatkan distribusi kadar hematokrit berdasarkan kelas NYHA. Jumlah terbanyak ialah NYHA kelas II sebesar $47,5 \%$. 
Tabel 1. Distribusi Pasien Gagal Jantung Kongestif Berdasarkan Kelas NYHA

\begin{tabular}{ccc}
\hline $\begin{array}{c}\text { Klasifikasi } \\
\text { NYHA }\end{array}$ & Jumlah & $\%$ \\
\hline Kelas I & 3 & 7,5 \\
Kelas II & 17 & 42,5 \\
Kelas III & 15 & 37,5 \\
Kelas IV & 5 & 12,5 \\
\hline Total & 40 & 100 \\
\hline
\end{tabular}

Tabel 2. Distribusi Kadar Hematokrit Berdasarkan Kelas NYHA

\begin{tabular}{cccc}
\hline $\begin{array}{c}\text { Klasifikasi } \\
\text { NYHA }\end{array}$ & $\begin{array}{c}\text { Kadar } \\
\text { Hematokrit } \\
(\%)\end{array}$ & $\begin{array}{c}\text { Jumlah } \\
\text { Pasien }\end{array}$ & $\%$ \\
\hline I & $30,2-34,8$ & 3 & 7,5 \\
II & $34,2-43,8$ & 17 & 47,5 \\
III & $36,0-47,2$ & 15 & 37,5 \\
IV & $43,5-53,2$ & 5 & 12,5 \\
Total & & 40 & 100 \\
\hline
\end{tabular}

Pada Tabel 3 perhitungan statistik korelasi Spearman-Rank memperlihatkan bahwa dari total sampel sebanyak 40 orang diperoleh koefisien korelasi $\mathrm{r}=0,558$ $(0,40-0,599=$ sedang $)$ dengan nilai $\mathrm{p}=0,000(\mathrm{p}<0,05)$.

Tabel 3. Hasil Uji Korelasi Spearman-Rank

\begin{tabular}{lcc}
\hline Variabel & $\begin{array}{c}\text { Niai } \\
\text { koefisien } \\
\text { korelasi } \\
(\mathrm{r})\end{array}$ & $\begin{array}{c}\text { Nilai } \\
\text { sig (p) }\end{array}$ \\
\hline $\begin{array}{c}\text { Kadar Hematokrit- } \\
\text { Kelas NYHA }\end{array}$ & 0,558 & 0,000 \\
\hline
\end{tabular}

Hal ini menyatakan terdapat tingkat hubungan yang sedang dan bermakna antara kadar hematokrit dengan kelas
NYHA. Selain itu, probabilitas koefisien korelasi (r) ini telah memenuhi taraf signifikan 0,05 dimana nilai sig $<\alpha=$ $0,000<0,05$ atau $5 \%$ kesalahan dari 100 \%. Pada Gambar 1 dapat dilihat bahwa terdapat peningkatan kadar hematokrit diikuti oleh peningkatan kelas NYHA.

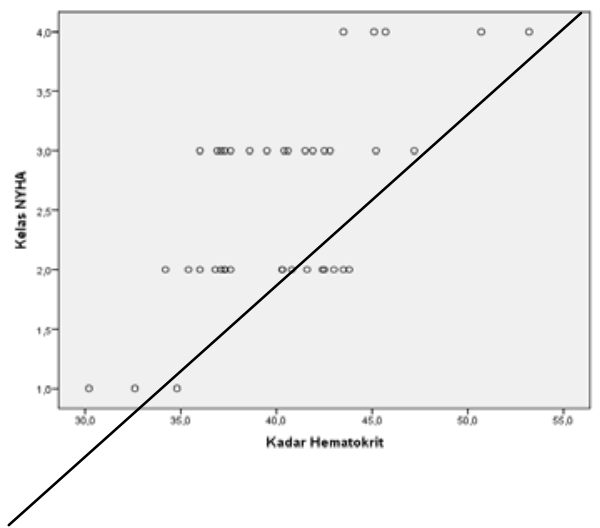

Gambar 1. Distribusi berdasarkan kadar hematokrit dan kelas NYHA pada gagal jantung kongestif

Dari Tabel 4 perhitungan statistik uji T independen di atas dapat dilihat bahwa dari total 40 orang yang terdiri dari 20 orang rawat jalan dan 20 orang inap, diperoleh nilai rata-rata kadar hematokrit pasien rawat jalan sebanyak 38,375, sedangkan nilai rata-rata kadar hematokrit pasien rawat inap sebanyak 42,165. Dari uji analisis data di atas juga diperoleh nilai $\mathrm{p}=0,008 \quad(\mathrm{p}<0,005)$ yang berarti bahwa terdapat perbedaan yang bermakna kadar hematokrit pada pasien gagal jantung kongestif yang dirawat jalan dan dirawat inap.

Tabel 4. Hasil Uji T Independen

\begin{tabular}{cccccc}
\hline Variabel & Kategori rawat & $\mathrm{N}$ & Mean & $\begin{array}{c}\text { Standar } \\
\text { Deviasi }\end{array}$ & Nilai P \\
\hline \multirow{2}{*}{ Kadar hematokrit } & Rawat Jalan & 20 & 38,375 & 3,8791 & 0,08 \\
\cline { 2 - 6 } & Rawat Inap & 20 & 42,165 & 4,6700 & 0,08 \\
\hline
\end{tabular}




\section{BAHASAN}

New York Heart Association pertama kali membuat klasifikasi gagal jantung berdasarkan pada derajat keterbatasan fungsional. Pembagian fungsional kelas NYHA sering digunakan untuk menentukan progresivitas gagal jantung. Pada penelitian ini didapatkan pasien yang paling banyak datang berobat ke Poliklinik Jantung datang dengan gagal jantung kongestif kelas fungsional II yaitu17 orang $(42,5 \%)$ dengan gejala berupa fatique, palpitasi, dan dispnea timbul pada saat aktivitas fisik biasa. Pasien dengan kelas fungsional III sebanyak 15 orang $(37,5 \%)$ dengan gejalanya saat istirahat, namun sedikit aktivitas menimbulkan gejala. Pasien dengan kelas fungsional IV sebanyak 5 orang $(12,5 \%)$ dimana pasien sudah menimbulkan gejala saat istirahat.

Kelas fungsional paling sedikit datang berobat ke Poliklinik Jantung ialah kelas fungsional I yaitu 3 orang (7,5\%) dimana tidak ada batasan aktivitas fisik dan tidak menimbulkan gejala sesak napas saat istirahat maupun aktivitas fisik. Kelas fungsional I dan II paling sering ditemukan pada pasien yang berobat jalan ke Poliklinik Jantung, sedangkan kelas fungsional III dan IV paling sering ditemukan di ruang rawat inap Cardiac Center dan Irina F. Pernyataan konsensus dalam (HFSA) menurut Hauptman er al. juga melaporkan pasien dengan gagal jantung yang dirawat inap merupakan pasien dengan kelas NYHA II dan IV. ${ }^{18}$

Berdasarkan hasil uji koefisien korelasi spearman-rank ditemukan adanya korelasi positif antara kadar hematokrit dengan klasifikasi NYHA dengan koefisien korelasi $r=0,558$ dengan $p=0,000$. Hasil ini menyatakan ada hubungan yang sedang dan bermakna hubungan kadar hematokrit dengan klasifikasi NYHA ( $<<0,05)$ pada pasien gagal jantung kongestif.

Hasil penelitian yang dilakukan didapatkan kadar hematokrit pada penderita gagal jantung kongestif kelas fungsional NYHA I, II, III, dan IV, namun hasil penelitian menunjukkan peningkatan yang paling tinggi terjadi pada kelas NYHA II,
III, dan IV. Dalam penelitian kohort Puerto Rico, hematokrit meningkat dikaitkan dengan merokok, berat badan relatif tinggi, tekanan darah tinggi, dan kolesterol serum yang lebih tinggi. Peningkatan kadar hematokrit dalam darah menyebabkan darah mengental sehingga mengurangi kecepatan aliran yang melewati pembuluh darah perifer dan menyebabkan perfusi oksigen ke jaringan menjadi berkurang sehingga dapat menimbulkan gejala. ${ }^{19}$ Hiperviskositas akibat peningkatan kadar hematokrit menurunkan kecepatan aliran balik vena ke jantung. Hal ini berarti bahwa mekanisme pengaturan tekanan darah biasanya dapat mengimbangi kecenderungan kenaikan viskositas darah untuk menaikkan tahanan perifer yang dengan demikian akan meningkatkan tekanan arteri tetapi di atas nilai tertentu, pengaturan ini dapat gagal dan timbul hipertensi. ${ }^{20}$

Keadaan hipertensi dapat menyebabkan kerusakan/cidera endotel yang bisa berakibat ke proses inflamasi berlanjut yang dapat menyebabkan ruptur plak aterosklerosis (trombosis). ${ }^{14}$

Aterosklerosis koroner merupakan salah satu kondisi yang mendasari penyebab kelainan fungsi otot jantung yang disebabkan menurunnya kontraktiltas jantung pada gagal jantung kongestif, salah satu faktor prediposisi aterosklerosis adalah kurangnya aktifitas fisik dan obesitas ${ }^{14}$. Proses inflamasi ateroklerosis ini bertambah cepat dan luas sehingga plak aterosklerosis ruptur. ${ }^{21}$ Pecahnya plak dapat menyebabkan terbentuknya trombus yang dapat menyebabkan iskemi berkepanjangan dengan infark miokard yang merupakan salah satu kausa dari gagal jantung akut. ${ }^{22}$ Dari hasil penelitian ini didapatkan peningkatan kadar hematokrit tertinggi pada kelas NYHA IV yaitu (43,553,2\%), kelas NYHA III yaitu (36,047,2\%), kelas NYHA II yaitu (34,2$43,8 \%)$, dan kelas I yaitu (30,2-34,8\%).

\section{SIMPULAN}

1. Terdapat tingkat hubungan yang sedang dan bermakna antara kadar hematokrit dan kelas NYHA pada 
pasien gagal jantung kongestif obesitas sentral yang dirawat jalan dan dirawat inap.

2. Peningkatan kadar hematokrit dapat meningkatkan kelas NYHA.

3. Terdapat perbedaan kadar hematokrit pada pasien gagal jantung kongestif yang dirawat jalan dan dirawat inap.

\section{DAFTAR PUSTAKA}

1. Brashers VL. Gagal Jantung Kongestif. In: Yulianti D, editor. Aplikasi Klinis Patofisiologi: Pemeriksaan dan Manajemen (Edisi II). Jakarta: EGC, 2007; p. 53.

2. Dumitru I. Heart Failure Clinical Presentation. Medscape. [cited 2014 Sep 15]. Available from: http://emedicine.medscape.com/article/ 163062-clinical\#a0256.

3. Anurogo D. Misteri Gagal Jantung. 2009. [cited 2014 Sep 15]. Available from: http://netsains.com/2009/08/misterigagal-jantung/.

4. American Heart Association. Heart Disease and Stroke Statistic-2006 Update. Dallas: AHA, 2006.

5. Houchens RL, Elixhauser A. Using the HCUP Nationwide Inpatient Sample to Estimate Trends. (Updated for 19882004). HCUP Methods Series Report \#2006-05 Online. August 18, 2006. U. S. Agency for Healthcare Research and Quality.

6. Hall MJ, Levant S, Defrances CJ. Hospitalization for Congestive Heart Failure:United States, 2000-2010. Centers for Disease Control and Prevention. 2012;108:1-8.

7. Laporan Nasional 2007. Riset Kesehatan Dasar (RISKESDAS) 2007. Badan Penelitian dan Pengembangan Kesehatan. Departemen Kesehatan, Republik Indonesia, Jakarta, Desember 2008.

8. Arief I. Jantung Koroner: Jangan Berujung Gagal Jantung. Pusat Jantung Nasional Harapan Kita. 7 Januari 2009. [cited 2014 Sep 15]. Available from: http://www.pjnhk.go.id/index.php?opti on=com_content\&task=view\&id=2136 \&1temid=31.

9. Kasron. Gagal Jantung. In: Haikhi, editor. Kelainan dan Penyakit Jantung
Pencegahan Serta Pengobatannya (Edisi I). Yogyakarta: NuhaMedika, 2012; p. 47-71.

10. Manurung D. Gagal Jantung Akut. In: Sudoyo AW, Setiyohadi B, Alwi I, Simadibrata M, Setiati S, editors. Buku Ajar Ilmu Penyakit Dalam Jilid 2 (Edisi V). Jakarta: Interna Publishing, 2010; p. 1586-88.

11. WHO. Media centre. Fact sheets. Obesity and Overwight. [cited 2014 Sep 15]. Available from: http://www.who.int/mediacentre/factsh eets/fs311/en/.

12. Laporan Nasional 2010. Riset Kesehatan Dasar (RISKESDAS) 2010. Badan Penelitian Pengembangan Kesehatan. Departemen Kesehatan, Republik Indonesia. Jakarta, Desember 2010.

13. Nursalim A, Yuniadi Y. Paradox Obesitas pada Pasien Gagal Jantung. Jurnal Kardiologi Indonesia. 2011;32:207-8.

14. Brashers VL. Dislipidemia dan Aterosklerosis. In: Yulianti D, editor. Aplikasi Klinis Patofisiologi: Pemeriksaan dan Manajemen (Edisi II). Jakarta: EGC, 2007; p. 17-25.

15. Bakta IM. Pendekatan Terhadap Pasien Anemia. In: Sudoyo AW, Setiyohadi B, Alwi I, Simadibrata M, Setiati S, editors. Buku Ajar Ilmu Penyakit Dalam Jilid 2 (Edisi V). Jakarta: Interna Publishing, 2009; p. 1109-15.

16. Price AS, Wilson ML. Komposisi Darah dan Sistem Makrofag-Monosit. In: Hartanto H, Wulansari P, Susi N, Mahanani DA, editors. Patofisiologi: Konsep Klinis Proses-Proses Penyakit (Edisi VI). Jakarta: EGC, 2005; p. 24753.

17. Georgre TI. Chronic Myeloproliperative Syndroms. In: Tkachuk DC, Hirschmann JV, editors. Wintrobes Atlas of Clinical Hematology. Philadelphia: Lippincott Williams \& Wilkins, 2007; p. 105-8.

18. Hauptman PJ, Rich MW, Heidenreich PA, Chin J, Cummings N, Dunlap ME, et al. The Heart Failure Clinic: A Consensus Statement of the Heart Failure Society of America. Journal of Cardiac Failure. 2008;14:801-15.

19. Puspitasari F, Harimurti GM. Hiperviskositas Pada Penyakit Jntung Bawaan (PJB) Sianotik. Jurnal 
Kardiologi Indonesia. 2010;31:41-7.

20. Guyton AC, Hall E J. Sel-Sel Darah Merah, Anemia, dan Polisitemia. In: Rahman YL, Hartanto H, Novrianti H, Wulandari N, editors. Buku Ajar Fisiologi Kedokteran (Edisi 11). Jakarta: EGC, 2008. p. 439-49.

21. Mukhtar D. Makrofag pada Jaringan Adiposa Obes sebagai Penanda
Terjadinya Resisten Insulin. Jakarta: Fakultas Kedokteran Universitas YARSI., 2012; p. 29-34.

22. Brashers VL. Penyakit Jantung Iskemik. In: Yulianti D, editor. Aplikasi Klinis Patofisiologi: Pemeriksaan dan Manajemen (Edisi II). Jakarta: EGC, 2007; p. 17-25. 